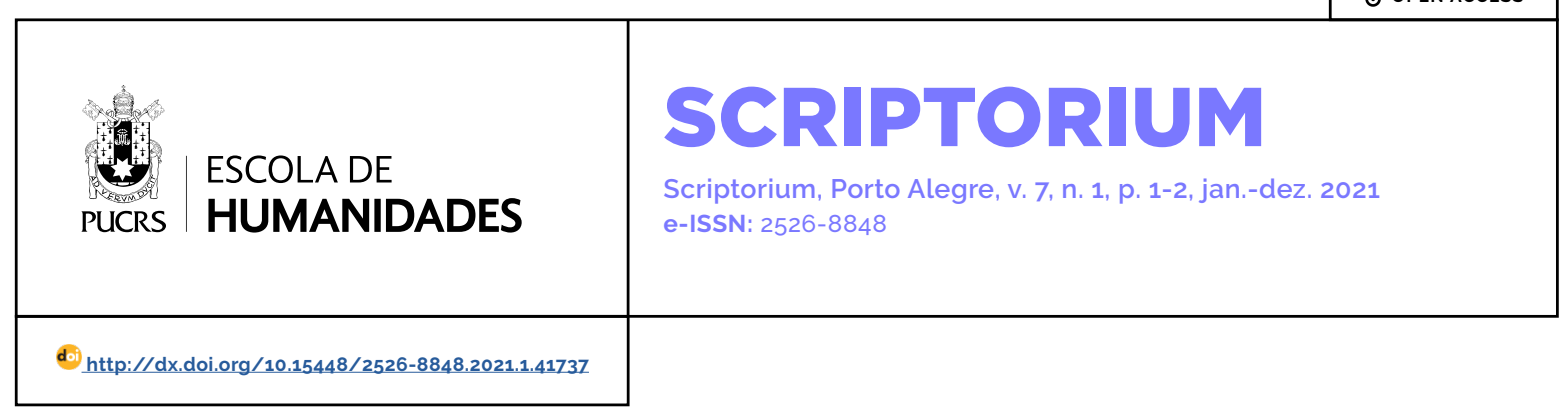

SEÇÃO: SCRIPTURA

\title{
À la cabral [ou Sobre soprar feijão]
}

À la cabral lor About blowing beans]

\section{Mélany Dias da Silveira ${ }^{1}$ orcid.org/0000-0003-1135-0113 melanysdias@gmail.com}

Recebido em: 21/10/2021. Aprovado em: 18/09/2021. Publicado em: 15/12/2021. projete seis palavras em verso todas sem sentido emocional dispense a cadência do metro para a essência do ritmo ser somente truncamento de difícil pronúncia de oclusivas velares vibrantes e severas consoantes

ordene seis versos em palavra sem sentido emocional e sólida fazendo soarem fluxos fricativos de ar suspendendo a passagem espontânea das sibilantes para ocluir com um obstáculo bucal que acabe com a corrente

edifique seis sentidos sólidos sem palavra emocional e verso a parecer simples sem nada a dizer senão palavras sólidas de versos sem sentidos que extrapolam o termo por ele mesmo e escapam na próxima linha

Buarque escreveu assim canção de proparoxitonas 


\section{Mélany Dias da Silveira}

Mestra em Letras, na área de Estudos da Linguagem, vinculada à linha de pesquisa Análises Textuais, Discursivas e Enunciativas pelo Programa de Pós-Graduação da Universidade Federal do Rio Grande do Sul (UFRGS), em Porto Alegre, RS, Brasil; e fonoaudióloga pela mesma instituição.

\section{Endereço para correspondência}

Mélany Dias da Silveira

Rua Brasil, 1100, casa 37

Centro, 92310-150

Canoas, RS, Brasil

Os textos deste artigo foram revisados por Poá Comunicação e submetidos para validação do(s) autor(es) antes da publicação. 